\title{
Composite $\beta$-K-casein genotypes and their effect on composition and coagulation of milk from Estonian Holstein cows
}

\author{
M. Vallas,${ }^{*} \dagger^{1}$ T. Kaart, ${ }^{*} \dagger$ S. Värv,${ }^{*} \dagger$ K. Pärna, $\ddagger$ I. Jõudu, ${ }^{*} \dagger$ H. Viinalass,${ }^{*} \dagger$ and E. Pärna*$\dagger$ \\ *Institute of Veterinary Medicine and Animal Sciences, Estonian University of Life Sciences, Kreutzwaldi 1, 51014 Tartu, Estonia \\ †Bio-Competence Centre of Healthy Dairy Products, Kreutzwaldi 1, 51014 Tartu, Estonia \\ łInstitute of Mathematical Statistics, University of Tartu, J. Liivi 2, 50409 Tartu, Estonia
}

\section{ABSTRACT}

The objective of this study was to estimate the effect of composite $\beta-\kappa-\mathrm{CN}$ genotypes on milk coagulation and composition traits, and on the additive genetic variation of these traits in Estonian Holstein dairy cattle. A total of 23,970 milk samples, repeated measurements from the first to third lactation from 2,859 Estonian Holstein cows from 78 herds across the country, were analyzed for milk yield, milk fat and protein percentages, somatic cell count, and milk coagulation properties (milk coagulation time and curd firmness). Each cow had at least 3 measurements per lactation. Two single-trait random regression animal models were fitted for the traits studied. The first model considered fixed effects of year-season of sampling and year-season of calving, calving age (nested within lactation), sample age (only for milk coagulation traits) and days in milk, and random herd, additive genetic, and permanent environmental effects. The animal and permanent environmental effects were modeled over the lactation period by using Legendre polynomials. The second model had the additional fixed $\beta$ - $\kappa$-casein effect in the form of a third-order Legendre polynomial. The 2 most frequent $\beta$ - $\kappa$-casein composite genotypes were $\mathrm{A} 2 \mathrm{~A} 2 \mathrm{AA}$ and A1A2AA, both with prevalence greater than $20 \%$. Percentages of the remaining 31 genotypes were less than $8 \%$, including 20 genotypes with percentages less than $1 \%$. The $\beta$ - $\kappa$-casein genotype-specific lactation curves were significantly different for milk coagulation traits and milk protein percentage. The $\mathrm{B}$ variant of $\kappa$-casein showed a favorable effect on both milk coagulation traits, whereas the IB haplotype had an increasing effect on curd firmness and protein percentage. Inclusion of the $\beta$ - $\kappa$-casein genotype effects in the model resulted in decreases in the mean additive genetic variations for milk coagulation time and curd firmness of 12.9 and $51.1 \%$, respectively.

Received March 1, 2012.

Accepted July 22, 2012.

${ }^{1}$ Corresponding author: mirjam.vallas@emu.ee
Key words: casein polymorphism, milk coagulation, Estonian Holstein dairy cattle

\section{INTRODUCTION}

Milk protein polymorphisms are often investigated in connection with milk performance traits. Some of these traits are hard to measure; therefore, milk protein polymorphisms promote a better understanding of the genetic background of milk production and offer an alternative indirect selection approach for improving milk quality. Many researchers have investigated associations between milk protein polymorphisms and milk production traits (Ng-Kwai-Hang et al., 1984; Bovenhuis et al., 1992; Boettcher et al., 2004) and protein composition (McLean et al., 1984; Heck et al., 2009; Bonfatti et al., 2010b). One of the most striking effects of milk protein polymorphisms on traits of economic interest is their relationship with the cheese-making properties of milk (see review by Caroli et al., 2009), including milk coagulation properties.

Some studies have found an association of genetic polymorphism of $\kappa$-CN with milk coagulation traits (Macheboeuf et al., 1993; Ikonen et al., 1997; Mayer et al., 1997) and protein percentage (Aleandri et al., 1990; Bovenhuis et al., 1992; Ikonen et al., 1999b), whereas the $\beta$-CN polymorphism was found to be related to fat percentage and fat and protein yields (Bovenhuis et al., 1992; Ikonen et al., 1999b). Many of the studies, however, had small sample sizes, with small coverage of the study population and limited variation in CN genotypes. Additionally, possibly because of the different breeds and different mathematical models used in the different studies, some results are inconsistent. Furthermore, because of the genetic linkage between the $\beta-\mathrm{CN}$ and $\kappa-\mathrm{CN}$ loci, composite $\beta-\kappa-\mathrm{CN}$ genotypes or haplotypes have been proposed for the estimation of CN genotype effects (Lundén et al., 1997; Ojala et al., 1997; Comin et al., 2008) on milk performance traits.

Recently, large-scale studies have been conducted (Comin et al., 2008; Bonfatti et al., 2010a; Penasa et al., 2010), enabling a more accurate adjustment for 
CN genotype effects in the estimation of the additive genetic variance component of milk composition and coagulation traits. However, few studies have reported the presence of the $\beta-\mathrm{CN}$ I allele (Bonfatti et al., 2010a,b; Visker et al., 2010), and no clear influence of this allele on milk coagulation traits has been reported. Furthermore, the authors are aware of only the smallsample-size study by Ikonen et al. (1997) using $\beta-\kappa-C N$ genotypes and repeated measurements, allowing the separation of variance components of additive genetic and permanent environmental effects in the model for analysis of variation in milk coagulation.

The aim of the present large-scale study, with repeated measurements, was to estimate the effect of composite $\beta-\kappa-\mathrm{CN}$ genotypes on the coagulation properties and composition of milk and on the additive genetic variation of these traits in the Estonian Holstein dairy population.

\section{MATERIALS AND METHODS}

\section{Data}

Milk samples from first- to third-lactation Estonian Holstein cows were collected during routine milk recording, as part of a development project for the Bio-Competence Centre of Healthy Dairy Products in Estonia, from April 2005 to May 2010. The herds were milked 2 or 3 times a day. The individual milk samples from each cow were collected either as a mixture of all test-day milkings from the cow or as only the morning, afternoon, or evening milking of the cow on the test day. Milk samples were immediately preserved with Bronopol (Knoll Pharmaceuticals, Nottingham, $\mathrm{UK}$ ) and stored at $4^{\circ} \mathrm{C}$ during the transportation and analysis periods. The individual milk samples of the cow were collected and analyzed for milk composition and coagulation traits, with intervals of 2 to 3 mo during lactation (7 to 305 DIM).

Milk samples were excluded if the $\mathrm{pH}$ was lower than 6.5, indicative of colostrum (Bhandari and Singh, 2002), the sample age was more than $12 \mathrm{~d}$ and, according to the recommendations of the International Committee for Animal Recording (ICAR, 2009), milk yield was less than $3 \mathrm{~kg}$, fat content was outside the range of 1.5 to $9 \%$, and protein content was outside the range of 1 to $7 \%$. Noncoagulated milk samples $(\mathrm{n}=138)$ were also removed. Further, individual cow lactations with fewer than 3 samples and herds with fewer than 5 cows were excluded.

The number of test-day records in the final data set was 23,970. Milk samples were collected from 2,859 Estonian Holstein cows (daughters of 229 sires) from
78 herds across the country. Each cow had 3 to 7 measurements per lactation. The number of daughters per sire varied from 1 to 177 . Additionally, a pedigree of 4 generations of animals was used, which included 20,791 animals.

Information about the cows, herds, and pedigree was obtained from the Estonian Animal Recording Centre (Tartu) and the Animal Breeders' Association of Estonia (Keava), and the database COAGEN, of the BioCompetence Centre of Healthy Dairy Products (Tartu, Estonia), was formed from these data.

\section{Milk Sample Analysis}

The test-day milk yield was recorded, and individual milk samples were analyzed for fat and protein percentages by using MilkoScan 4000 and MilkoScan FT6000 instruments (FOSS, Hillerød, Denmark), and for SCC by using Fossomatic 4000 and Fossomatic 5000 cell counters (FOSS), at the Milk Analysis Laboratory of the Estonian Animal Recording Centre, using methods suggested by the International Committee for Animal Recording (ICAR, 2009). Milk sample analysis included all individual milk samples, including milk samples collected as a mixture of all test-day milkings of the cow. Somatic cell count values were log-transformed to SCS: $\mathrm{SCS}=\log _{2}(\mathrm{SCC} / 100,000)+3$.

The $\mathrm{pH}$ and milk coagulation properties were determined at the Milk Quality Laboratory of the Estonian University of Life Sciences, as described by Vallas et al. (2010). Briefly, a pH meter (Seven Multi, Mettler Toledo GmbH, Greifensee, Switzerland) was used for determination of the $\mathrm{pH}$ level of the milk before measuring milk coagulation time (RCT, min) and curd firmness $\left(\mathbf{a}_{30}, \mathrm{~V}\right)$, which were determined using an Optigraph (Ysebaert, Frepillon, France).

\section{Genotyping of Milk Protein Variants}

Genotyping was carried out in the Animal Genetics Laboratory at the Estonian University of Life Sciences and the database COACAS, of the Bio-Competence Centre of Healthy Dairy Products, was formed. Blood samples were collected in tubes containing $\mathrm{K}_{3}$ EDTA. Deoxyribonucleic acid was extracted from whole blood using a commercial Genomic DNA Purification Kit (MBI Fermentas, Vilnius, Lithuania) and a Puregene DNA Purification System for Laboratory Use Blood Kit (Gentra Systems, Minneapolis, MN). The CN gene polymorphisms (SNP) were analyzed on the basis of nucleotide exchanges in codons 67, 93, 106, and 122 of exon 7 in the $\beta$-CN gene (determining the variants A1, A2, A3, B, and I) and in codons 148 and 155 of 
exon 4 in the ${ }^{\kappa}-\mathrm{CN}$ gene (A, $\mathrm{B}$, and $\mathrm{E}$ variants). The primer design was based on GenBank sequence X14711 for primer-specific PCR (allele-specific oligonucleotide$\mathrm{PCR}$ ) to detect polymorphisms in the $\beta-\mathrm{CN}$ gene. Using the present set of primers enabled discrimination of the I allele, previously genotyped as A2. Polymorphisms in the $\mathrm{k}$-CN gene were analyzed according to the method described by Velmala et al. (1993), applying restriction analysis (restriction fragment length polymorphismPCR). The restriction fragment length polymorphismPCR and allele-specific oligonucleotide-PCR products were visualized by electrophoresis on $2 \%$ agarose gel and documented using Bio-Capt v. 12.5 software (Vilbert Lourmant, France). Samples with various milk protein genotypes were verified using DNA sequencing of the relevant chromosomal regions. Sequencing was performed using a BigDye Terminator v3.1 Cycle Sequencing Kit (Applied Biosystems, Carlsbad, CA) and analyzed using an ABI Prism 3130 Genetic Analyzer (Applied Biosystems).

\section{Statistical Analysis}

Two single-trait random regression animal models were applied to the studied traits. The full model was

$$
\begin{gathered}
y_{i j k l m n}(t)=\mu+\sum_{p=1}^{3} b_{p} \lg _{p}(t)+\sum_{p=0}^{3} c_{i p} \lg _{p}(t)+F_{j}+h_{k} \\
+\sum_{p=0}^{q} a_{l p} \lg _{p}(t)+\sum_{p=0}^{r} p e_{m p} \lg _{p}(t)+\varepsilon_{i j k l m n}(t),
\end{gathered}
$$

where $y_{i j k l m n}(t)$ is the observation of milk coagulation traits ( $\mathrm{RCT}$ and $\mathrm{a}_{30}$ ), milk yield, protein percentage, fat percentage, or SCS on the th day in milk; $\mu$ is the overall mean; $\lg _{p}(t)$ is the $p$ th-order Legendre polynomial of the th DIM; $b_{p}$ is a fixed regression coefficient of the $p$ th-order Legendre polynomial; $c_{i p}$ is a fixed genotype-specific regression coefficient; $F_{j}$ indicates a subclass of other fixed effects, including calving age (nested within lactation), sample age (only for milk coagulation traits), year-season of sampling, and yearseason of calving; $h_{k}$ is random herd effect; $a_{l p}$ is a random animal-specific regression coefficient of the $q$ thorder Legendre polynomial; $p e_{m p}$ is a random permanent environment-specific regression coefficient of the $r$ thorder Legendre polynomial; and $\varepsilon_{i j k l m n}(t)$ is the random error term. Orders $q$ and $r$ varied from 0 to 3, depending on the trait studied. The reduced model was the full model without the $\beta$ - $\kappa$-CN genotype effect $\sum_{p=0}^{3} c_{i p} \lg _{p}(t)$.

The analyses were performed using ASReml (Gilmour et al., 2002). Further, composite genotype-specific lactation curves and dynamics of additive genetic variation during lactation were evaluated in SAS software version 9.2 (SAS Institute, 2008) based on the regression coefficients and covariance matrices of Legendre polynomials, respectively. Lactation total genotype effects for milk composition and coagulation traits were calculated as sums of differences between daily values of average and genotype-specific lactation curves obtained by the full model.

\section{RESULTS AND DISCUSSION}

\section{Descriptive Statistics}

Descriptive statistics for milk yield, composition, and coagulation traits are presented in Table 1 . The number of test-day records was much higher in the first lactation; in the second and the third lactations, the number of cows decreased along with the number of test-day records.

Genotype frequencies of $\beta-\kappa-C N$ genotypes are shown in Table 2. Two genotypes, A2A2AA and A1A2AA, were more frequent than the rest, with percentages of 27.4 and $23.1 \%$, respectively. The percentages of the remaining 31 genotypes were less than $8 \%$, including 20 genotypes with percentages less than $1 \%$. These genotype frequencies were similar to those reported for Italian Holstein cows (Comin et al., 2008). Genotype A1IAE appeared only once and was therefore excluded

\begin{tabular}{|c|c|c|c|c|}
\hline Trait & $\begin{array}{l}\text { First lactation } \\
(\mathrm{n}=11,699)\end{array}$ & $\begin{array}{l}\text { Second lactation } \\
\quad(\mathrm{n}=7,917)\end{array}$ & $\begin{array}{l}\text { Third lactation } \\
(\mathrm{n}=4,354)\end{array}$ & $\begin{array}{c}\text { Total } \\
(\mathrm{n}=23,970)\end{array}$ \\
\hline Milk coagulation time, min & $10.65 \pm 2.50$ & $10.30 \pm 2.04$ & $9.51 \pm 1.76$ & $10.32 \pm 2.27$ \\
\hline Fat, $\%$ & $4.05 \pm 0.69$ & $4.07 \pm 0.80$ & $4.07 \pm 0.81$ & $4.06 \pm 0.75$ \\
\hline Protein, \% & $3.36 \pm 0.31$ & $3.39 \pm 0.35$ & $3.38 \pm 0.35$ & $3.38 \pm 0.33$ \\
\hline $\mathrm{SCS}^{1}$ & $2.85 \pm 1.88$ & $3.52 \pm 2.01$ & $3.81 \pm 2.01$ & $3.25 \pm 1.99$ \\
\hline
\end{tabular}

Table 1. Descriptive statistics for milk coagulation and composition traits per lactation (mean \pm SD)

${ }^{1} \mathrm{SCS}=\left[\log _{2}(\mathrm{SCC} / 100,000)+3\right]$. 
Table 2. Distribution of casein genotypes [no. (\%)]: marginal genotype frequencies of $\beta$-casein (last column), $\kappa$-CN (upper row) and frequencies of composite $\beta$ - $\kappa$-casein genotypes

\begin{tabular}{|c|c|c|c|c|c|c|c|}
\hline $\begin{array}{l}\beta-\mathrm{CN} \\
\text { genotype }\end{array}$ & \multicolumn{6}{|c|}{$\kappa$-CN genotype } & Total no. (\%) \\
\hline A1A1 & $112(3.9)$ & $44(1.5)$ & $70(2.4)$ & $3(0.1)$ & $17(0.6)$ & $8(0.3)$ & $254(8.9)$ \\
\hline A1A2 & $659(23.1)$ & $210(7.3)$ & $213(7.5)$ & $18(0.6)$ & $29(1.0)$ & & $1,129(39.5)$ \\
\hline $\mathrm{A} 1 \mathrm{~B}$ & & $43(1.5)$ & & $12(0.4)$ & $9(0.3)$ & & $64(2.2)$ \\
\hline $\mathrm{A} 2 \mathrm{~A} 3$ & $5(0.2)$ & & & & & & $5(0.2)$ \\
\hline $\mathrm{A} 2 \mathrm{~B}$ & $2(0.1)$ & $76(2.7)$ & & $10(0.3)$ & & & $88(3.1)$ \\
\hline $\mathrm{A} 2 \mathrm{I}$ & & $179(6.3)$ & & $19(0.7)$ & & & $198(7.0)$ \\
\hline $\mathrm{BB}$ & & $3(0.1)$ & & $6(0.2)$ & & & $9(0.3)$ \\
\hline BI & & $2(0.1)$ & & $14(0.5)$ & & & $16(0.6)$ \\
\hline II & & & & $12(0.4)$ & & & $12(0.4)$ \\
\hline
\end{tabular}

from further statistical analyses. A Dutch HolsteinFriesian investigation inferring $\beta-\kappa-\mathrm{CN}$ haplotypes showed that $\beta$-CN protein variant I occurred only with $\kappa-\mathrm{CN}$ variant B (Visker et al. 2010). The very rare $\beta-\kappa-$ CN genotype A1IAE showed the presence of different combinations of the $\beta$-CN I allele with the $\kappa-\mathrm{CN}$ variant other than the B allele in our study. However, of 344 animals having at least $1 \beta$-CN I allele, 343 also had at least $1 \kappa-\mathrm{CN} \mathrm{B}$ allele. The rare $\kappa$-CN genotype $\mathrm{EE}$ was associated only with the $\beta$-CN A1A1 genotype. Genotypes $\mathrm{BE}$ and $\mathrm{AE}$ of $\kappa-\mathrm{CN}$ were also mainly as- sociated with $\beta-\mathrm{CN}$ genotypes that included the A1 allele. The $\beta-\kappa-\mathrm{CN}$ A1E haplotype was also observed in the popular Finnish Ayrshire bull Mäkimattilan Inssi in the study by Velmala et al. (1995), in which the E allele was exclusively found in this haplotype.

\section{$\beta-k-C N$ Genotype Effects on Milk Composition and Coagulation Traits}

Associations between $\beta-\kappa-\mathrm{CN}$ genotypes and milk composition and coagulation traits are presented in

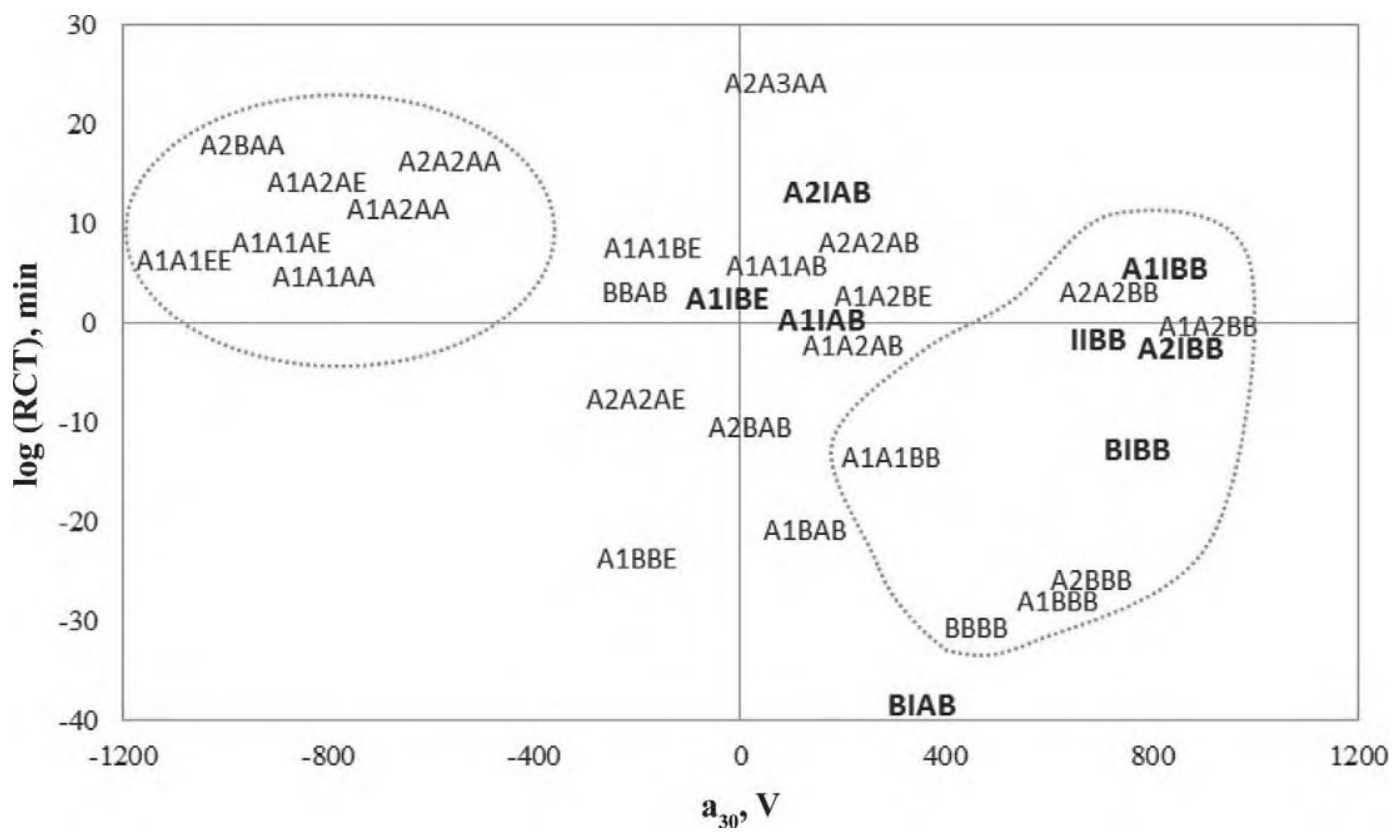

Figure 1. Estimated total $\beta$ - $\kappa$-CN genotype effects for curd firmness $\left(\mathrm{a}_{30}\right)$ and log-transformed milk coagulation time $[\log (\mathrm{RCT})]$ as deviations from the overall mean. The genotypes in bold are those including the $\beta$-CN I allele; the 2 groups of genotypes surrounded by dotted lines comprise the $\kappa$-CN BB genotype (composite genotypes of favorable coagulation) or exclude the $\kappa$-CN B allele (except for 2 rare variants; composite genotypes of unfavorable coagulation), respectively. 


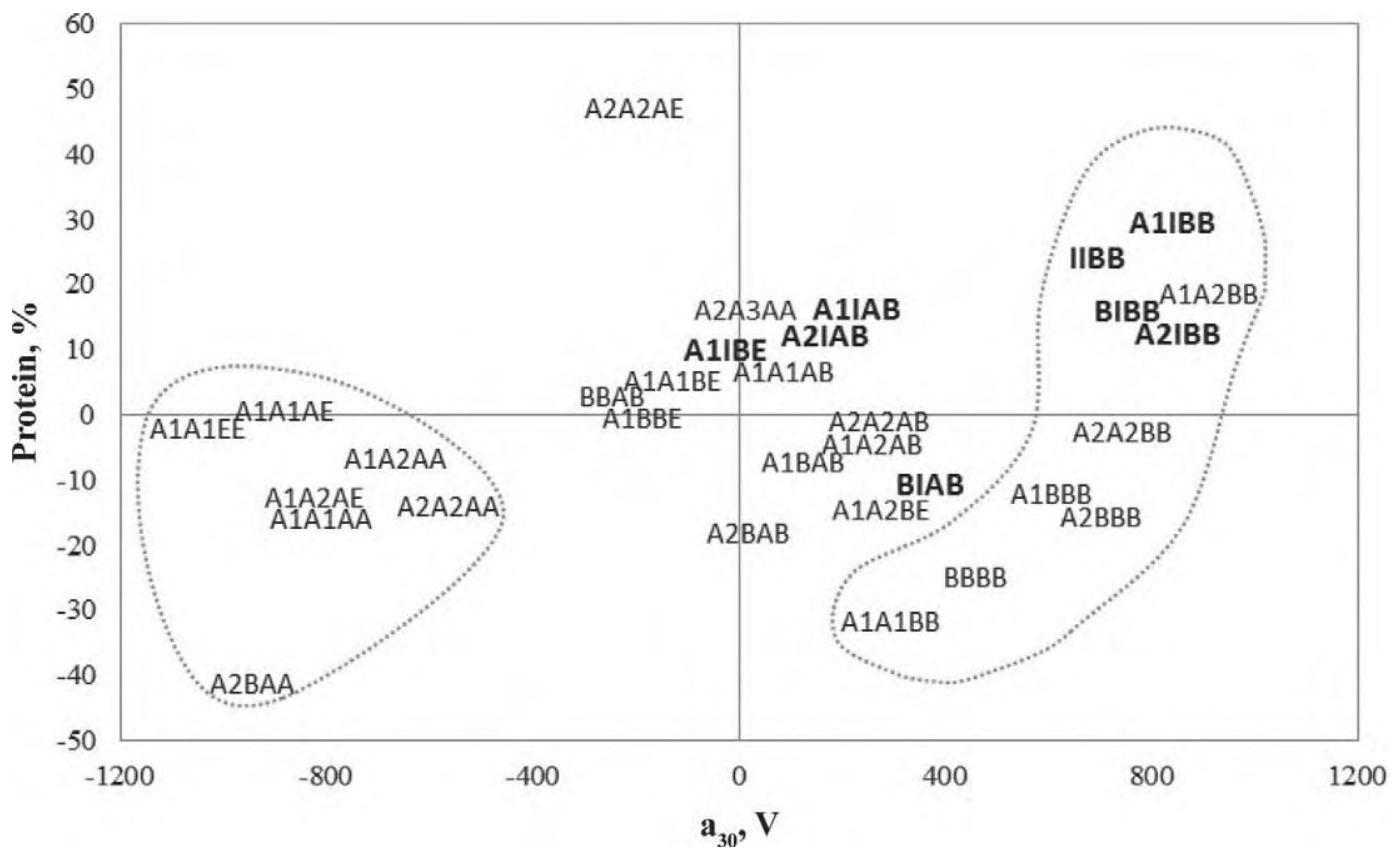

Figure 2. Estimated total $\beta-\kappa-C N$ genotype effects for protein percentage and curd firmness $\left(\mathrm{a}_{30}\right)$ as deviations from the overall mean. Genotypes in bold are those including the $\beta$-CN I allele; the 2 groups of genotypes surrounded by dotted lines comprise the $\kappa$-CN BB genotype or exclude the $\kappa$-CN B allele (except for 2 rare variants), respectively.

Figures 1,2 , and 3 . For the presented traits, the significance values of a $\beta-\kappa-C N$ genotype effect were $P<$ 0.001 for the RCT, $\mathrm{a}_{30}$, and protein percentage and $P$ $=0.096$ for the fat percentage. Additionally, dynamics of $\beta-\kappa-C N$ genotype effects on milk coagulation traits and protein percentage during lactation are shown in Figures 4, 5, and 6 .

The association of $\beta-\kappa-\mathrm{CN}$ genotypes with milk coagulation traits indicates that the genotypes related to the higher values of $\mathrm{a}_{30}$ also corresponded to a shorter RCT (Figure 1). The favorable $\beta-\kappa-C N$ genotypes increasing the $\mathrm{a}_{30}$ and decreasing the RCT comprised genotype $\mathrm{BB}$ of $\kappa-\mathrm{CN}$, whereas the unfavorable genotypes decreasing the $\mathrm{a}_{30}$ and increasing the RCT excluded the $\mathrm{B}$ allele of $\kappa-\mathrm{CN}$ (including 2 more frequent genotypes, A2A2AA and A1A2AA). These groups, based on the $\kappa-\mathrm{CN}$ genotype in the $\beta-\kappa-\mathrm{CN}$ composite genotype, are designated with dotted lines in Figure 1. A similar effect of the $\kappa-\mathrm{CN} B$ allele was reported by Comin et al. (2008). As in the studies by Comin et al. (2008) and Bonfatti et al. (2010a), a favorable effect of the $\beta$-CN B allele on milk coagulation traits was found in the present study. As indicated by groups based on $\kappa$-CN genotypes (Figure 1), however, $\kappa-\mathrm{CN}$ seemed to have a greater influence on these traits, as was also suggested by Comin et al. (2008). Furthermore, the order of $3 \kappa$-CN genotypes was clear for $\mathrm{a}_{30}$ in the $\beta-\kappa-\mathrm{CN}$ composite genotypes: $\mathrm{BB}>\mathrm{AB}>\mathrm{AA}$
(Figures 1 and 2). This order of $\kappa-\mathrm{CN}$ genotypes corresponded to the concentration and proportion of $\kappa-\mathrm{CN}$ described by McLean et al. (1984), Ikonen et al. (1997), and Hallén et al. (2008). Therefore, the association of the $\kappa_{-} \mathrm{CN} \mathrm{B}$ variant with milk coagulation traits may be due to an alteration in protein composition, as was also suggested by Bonfatti et al. (2010a). No clear superiority of genotypes was observed, including the $\beta$-CN I allele for either of the milk coagulation properties. However, genotypes including the I allele were all (with one exception) above the $\mathrm{a}_{30}$ mean and were close to the mean for RCT. Only the A1IBE genotype showed an unfavorable effect for both milk coagulation traits, which might have been caused by the negative effect of the $\kappa$-CN E allele on milk coagulation, as previously reported by Ojala et al. (2005) and Hallén et al. (2007).

Genotype BB of $\kappa-\mathrm{CN}$ showed no association with protein percentage, whereas the group of genotypes lacking the $\mathrm{B}$ allele of $\kappa$ - $\mathrm{CN}$ (excluding the rare genotypes $\mathrm{A} 2 \mathrm{~A} 2 \mathrm{AE}$ and $\mathrm{A} 2 \mathrm{~A} 3 \mathrm{AA}$, where the effect may be uncertain) corresponded to a lower protein percentage (Figure 2). The latter result is in accordance with previous studies of Bonfatti et al. (2010b) and Visker et al. (2010) but disagrees with the result of Comin et al. (2008), who found no association between protein percentage and $\kappa$-CN genotypes. The I allele of $\beta-\mathrm{CN}$ had a positive effect on protein percentage. This result confirms the report by Visker et al. (2010), who also 


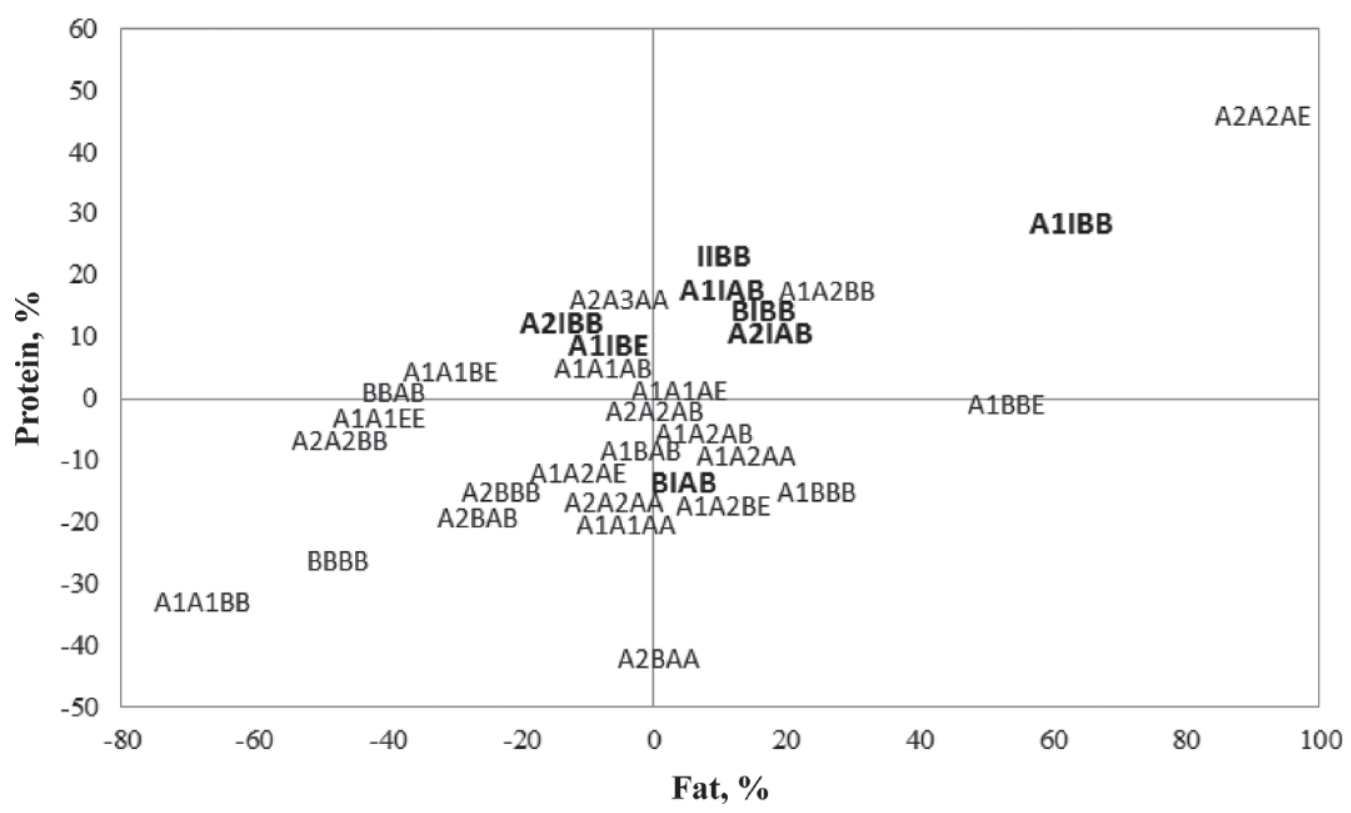

Figure 3. Estimated total $\beta$ - $-\mathrm{CN}$ genotype effects for fat percentage and protein percentage as deviations from the overall mean. Genotypes in bold are those including the $\beta$-CN I allele.

found a positive effect of the $\beta$-CN I variant on protein percentage. The favorable association of $\beta-\kappa-\mathrm{CN}$ haplotype IB with protein percentage, however, seemed to occur from the positive effect of the $\beta$-CN I variant rather than from the effect of the $\kappa-\mathrm{CN} \mathrm{B}$ variant (Figure 2). At the same time, all genotypes (except one) potentially incorporating the $\beta-\kappa-C N$ haplotype IB had a positive effect on $\mathrm{a}_{30}$ (Figures 1 and 2), confirming the favorable effect of this haplotype on $\mathrm{a}_{30}$. The positive effect of $\beta-\kappa-C N$ haplotype IB on $\mathrm{a}_{30}$ has not been reported previously. A slight increase in the protein percentage associated with haplotype IB has also been reported by Bonfatti et al. (2010b).

Genotypes related to a higher protein percentage were also related to a higher fat percentage (Figure 3 ), but no specific groups of genotypes could be determined. The effect of the $\beta-\kappa-C N$ genotype on milk yield and SCS was not significant. These results agree with those in previous studies by Comin et al. (2008), Bonfatti et al. (2010b), and Visker et al. (2010). However, the 2 more frequent $\beta$ - $\kappa-\mathrm{CN}$ genotypes, A2A2AA and A1A2AA, had a moderately positive effect on milk yield albeit not statistically significant.

\section{$\beta-\kappa-C N$ Genotype Effects on Additive Genetic Variance of Milk Traits}

The $\beta$ - $-\mathrm{CN}$ genotype-specific lactation curves were significantly different for milk coagulation traits and milk protein percentage $(P<0.05)$. The analysis of covariance functions showed that the $\beta-\kappa-\mathrm{CN}$ genotype

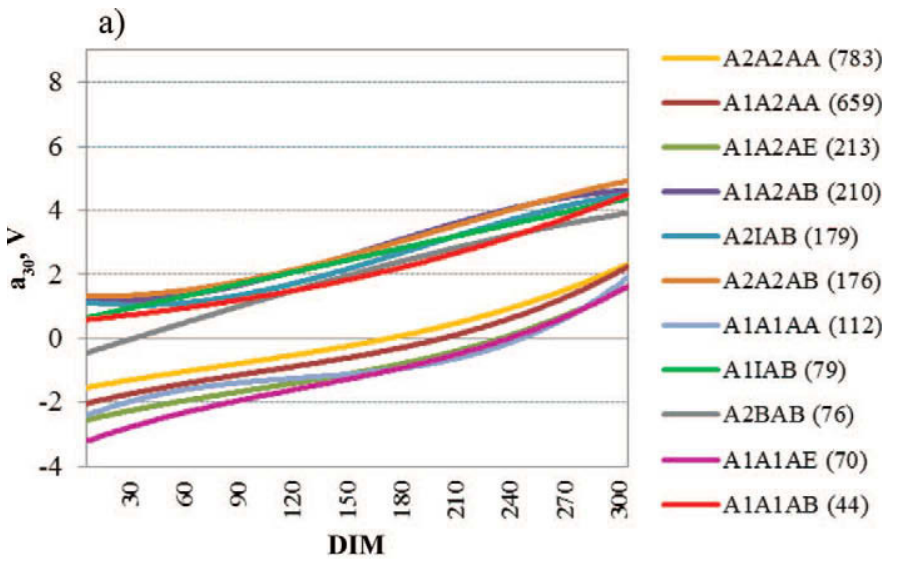

b)

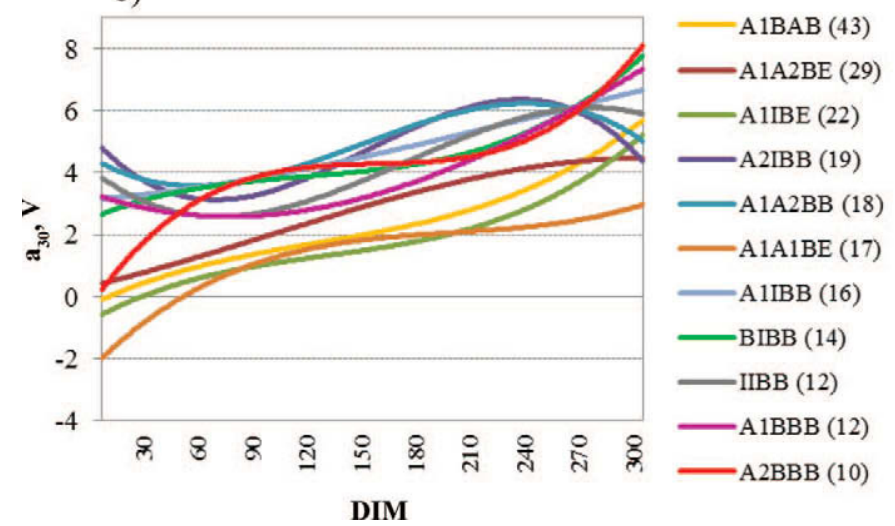

Figure 4. Genotype-specific curves for $\beta-\kappa-\mathrm{CN}$ genotypes with a frequency above 10 for curd firmness $\left(\mathrm{a}_{30}\right)$. The genotypes with higher frequencies are presented in panel a, and less frequent genotypes are presented in panel b. Genotype frequencies are presented in parentheses. Color version available in the online PDF.

Journal of Dairy Science Vol. 95 No. 11, 2012 

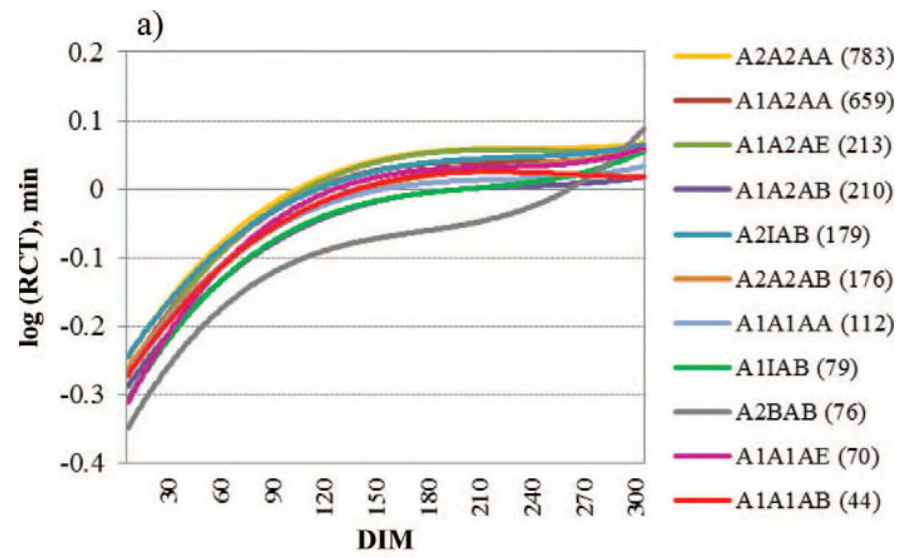

b)

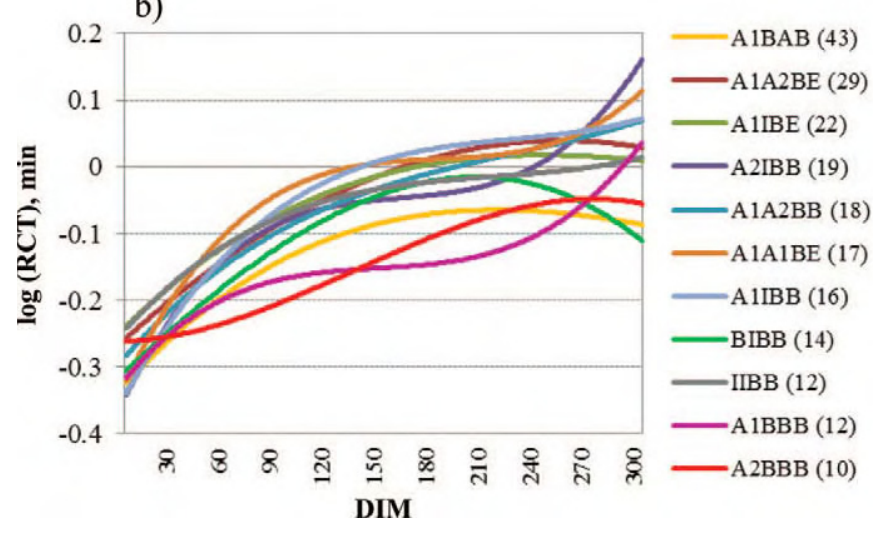

Figure 5. Genotype-specific curves for $\beta-\kappa-\mathrm{CN}$ genotypes with a frequency above 10 for log-transformed milk coagulation time $[\log (\mathrm{RCT})]$. The genotypes with higher frequencies are presented in panel a, and less frequent genotypes are presented in panel b. Genotype frequencies are presented in parentheses. Color version available in the online PDF.

effect mainly caused changes in the proportion of additive genetic variation, whereas the dynamics (the shape of the curve) remained largely the same (Figure 7 ).

Inclusion of a $\beta-\kappa-C N$ genotype effect into the model resulted in a decrease in the mean additive genetic variance by $12.9 \%$ for RCT, and by $51.1 \%$ for $\mathrm{a}_{30}$ (Table 3 ). The result for $\mathrm{a}_{30}$ was similar to the decrease of $68 \%$ reported by Penasa et al. (2010), whereas the decrease for RCT was comparable with the $20 \%$ decrease described by Ikonen et al. (1999a). However, the study by Ikonen et al. (1999a) included both Finnish Friesian and Finnish Ayrshire breeds and additionally considered a $\beta$-LG effect. Similar to the reports by Penasa et al. (2010) and Ikonen et al. (1999a), the $\beta-\kappa-C N$ genotype effects on milk yield, protein and fat percentages, and SCS additive genetic variance were marginal. The cows in the studies by Penasa et al. (2010) and Ikonen et al. (1999a) were sampled only once; consequently, the animal models in these studies did not include a permanent environmental variance component, which may have caused some of the difference in their results compared with the present study regarding the effect of milk protein polymorphism on the additive genetic variance. Analyses of the permanent environmental variance showed that the inclusion of a $\beta-\kappa-\mathrm{CN}$ genotype effect caused an increase in this parameter (Table $3)$. Inclusion of the $\beta-\kappa-\mathrm{CN}$ genotype effect allowed more precise distinction of the additive genetic and the animal-specific permanent effects, which could explain the increase in permanent environmental variance.

\section{CONCLUSIONS}

This study included 2,859 Estonian Holstein cows. The most frequent $\beta-\kappa-\mathrm{CN}$ composite genotypes were $\mathrm{A} 2 \mathrm{~A} 2 \mathrm{AA}$ and $\mathrm{A} 1 \mathrm{~A} 2 \mathrm{AA}$, both with prevalence greater than $20 \%$. These genotypes had unfavorable effects on RCT and $\mathrm{a}_{30}$. Of the 344 animals that had at least 1

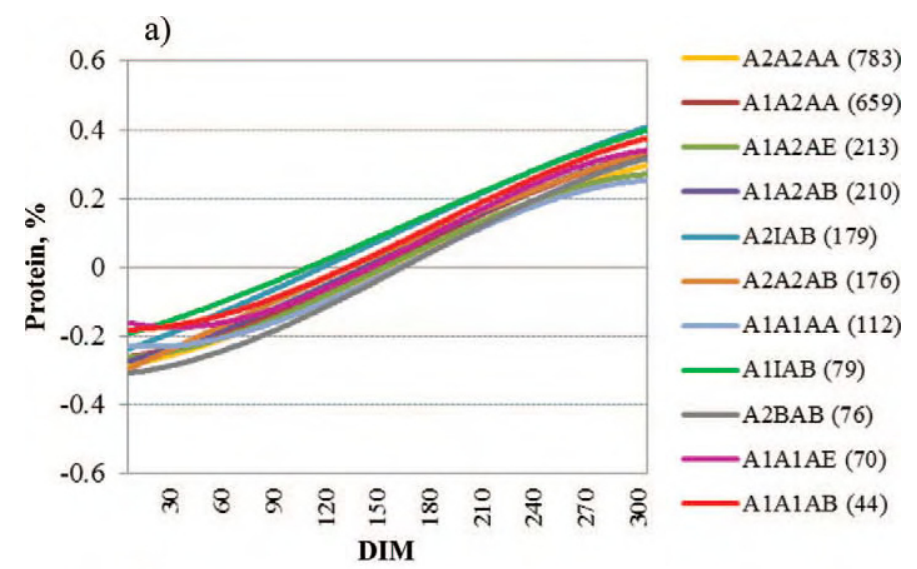

b)

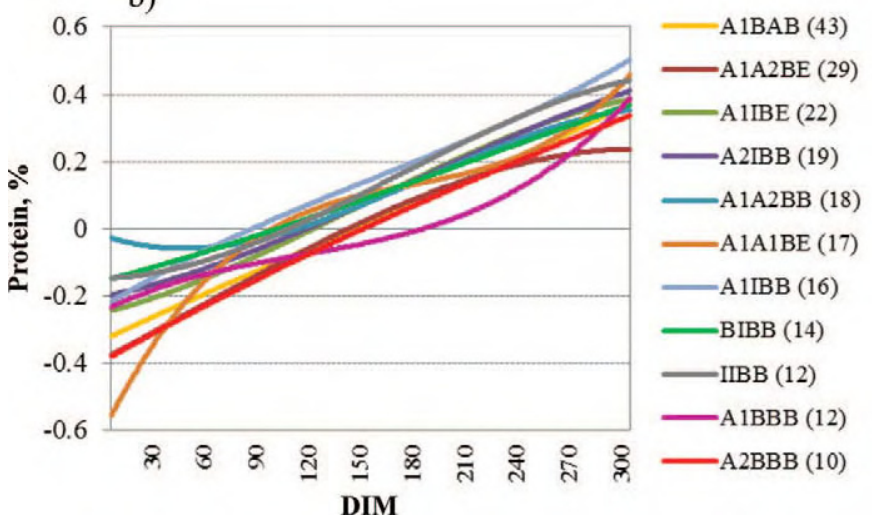

Figure 6. Genotype-specific curves for $\beta-\kappa-C N$ genotypes with a frequency above 10 for protein percentage. The genotypes with higher frequencies are presented in panel a, and less frequent genotypes are presented in panel b. Genotype frequencies are presented in parentheses. Color version available in the online PDF. 
Table 3. Lactation curve means for dispersion components of the additive genetic $\left(\sigma_{\mathrm{a}}^{2}\right)$ and permanent environmental $\left(\sigma^{2}\right.$ pe $)$ effects, estimated with random regression animal models excluding or including the $\beta$ - $\kappa$-CN genotype effect (models 1 and 2, respectively)

\begin{tabular}{|c|c|c|c|c|c|c|}
\hline Trait & \multicolumn{2}{|c|}{ Mean of $\sigma_{a}^{2}$} & $\begin{array}{c}\begin{array}{c}\text { Relative } \\
\text { difference }\end{array} \\
\begin{array}{c}\text { Model } 2 \\
\text { model } 1,{ }^{1} \%\end{array}\end{array}$ & \multicolumn{2}{|c|}{ Mean of $\sigma_{\text {pe }}^{2}$} & $\begin{array}{c}\begin{array}{c}\text { Relative } \\
\text { difference }\end{array} \\
\begin{array}{c}\text { Model } 2 \\
\text { model } 1,{ }^{1} \%\end{array}\end{array}$ \\
\hline $\log (\mathrm{RCT}),{ }^{2} \min$ & 0.0107 & 0.0093 & -12.9 & 0.0031 & 0.0035 & 14.6 \\
\hline Curd firmness, $\mathrm{V}$ & 7.1483 & 3.4949 & -51.1 & $\mathrm{NE}^{3}$ & 1.0809 & $\mathrm{NE}$ \\
\hline Milk yield, kg/d & 10.7748 & 10.3217 & -4.2 & 8.0809 & 8.4902 & 5.1 \\
\hline $\mathrm{SCS}^{4}$ & 0.2189 & 0.2207 & 0.8 & 0.7950 & 0.7968 & 0.2 \\
\hline
\end{tabular}

${ }^{1}[$ Model 2 - model 1)/model 2] × 100 .

${ }^{2}$ Log-transformed milk coagulation time.

${ }^{3} \mathrm{NE}=$ not estimable.

${ }^{4} \mathrm{SCS}=\left[\log _{2}(\mathrm{SCC} / 100,000)+3\right]$.
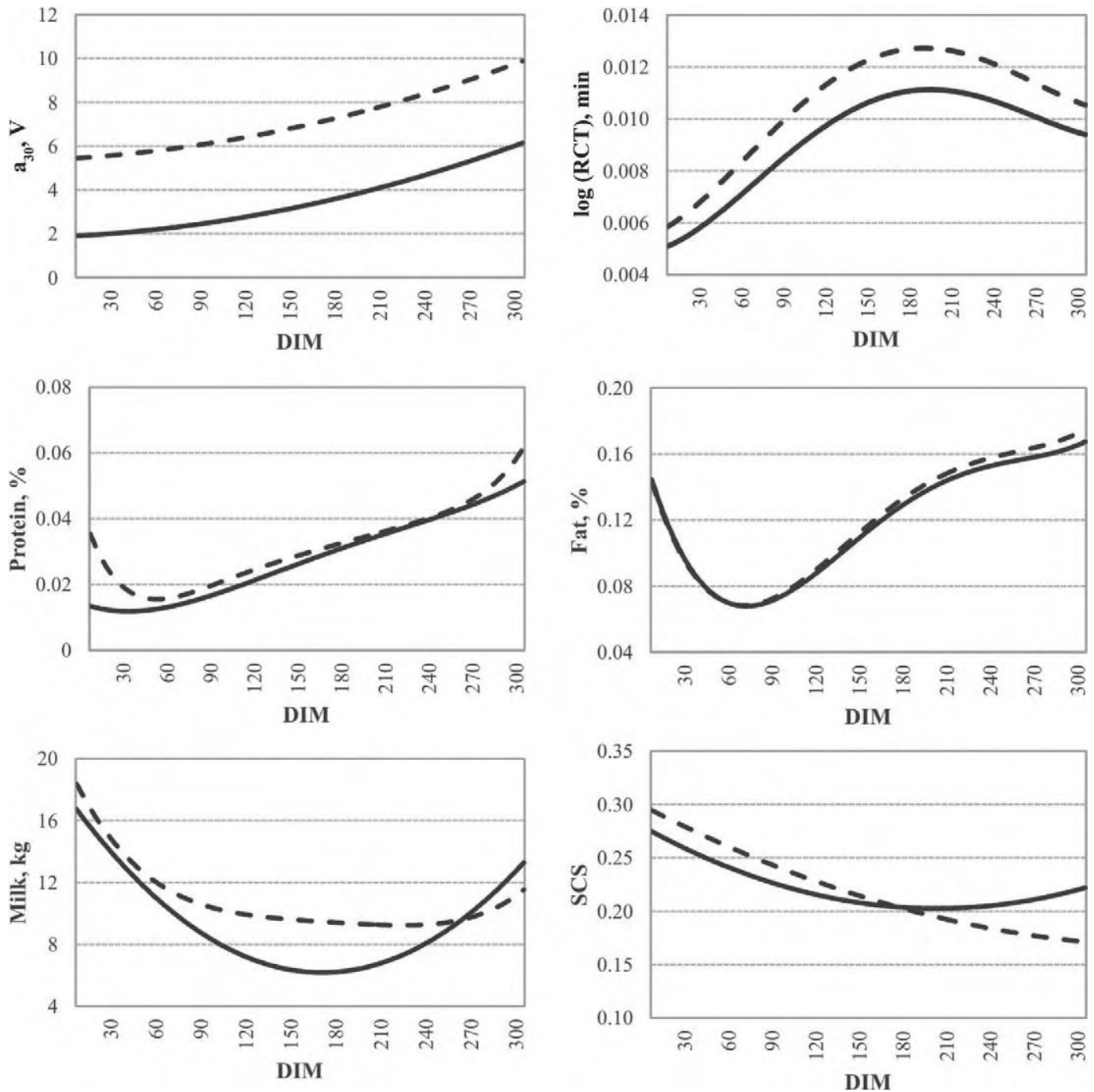

Figure 7. Dynamics of additive genetic variance of milk coagulation $\left[\log (\mathrm{RCT})\right.$ and $\left.\mathrm{a}_{30}\right]$ and composition traits during lactation $(7$ to 305 DIM) considering the $\beta$ - $-\mathrm{CN}$ genotype effect (solid line) and excluding the $\beta$ - $\kappa$-CN genotype effect (dashed line) as a third-order Legendre polynomial of DIM. $\mathrm{a}_{30}=$ curd firmness; $\log (\mathrm{RCT})=\log$-transformed milk coagulation time. 
$\beta$-CN I allele, 343 also had at least $1 \kappa$-CN B allele, a strong indication of the existence of a $\beta-\kappa-C N$ IB haplotype. The $\mathrm{B}$ variant of $\kappa-\mathrm{CN}$ showed a favorable effect on both milk coagulation traits, whereas the IB haplotype had an increasing effect on $\mathrm{a}_{30}$ and protein percentage. The composite $\beta-\kappa-C N$ genotypes influenced the additive genetic variance of milk coagulation traits, whereas changes in the additive genetic variance of milk composition traits were marginal.

Thus, considering the high frequency of unfavorable $\beta-\kappa-\mathrm{CN}$ genotypes for milk coagulation traits, and the positive association of the $\beta-\kappa-C N$ IB haplotype with $\mathrm{a}_{30}$ and protein percentage, selection based on the $\beta-\kappa-$ CN genotype for these traits could be a consideration. Genetic improvement is expected to be higher for milk coagulation properties because the influence of the $\beta-\kappa-$ $\mathrm{CN}$ genotype on the additive genetic variation of these milk properties was stronger than its influence on the additive genetic variation of milk composition traits.

\section{ACKNOWLEDGMENTS}

The research leading to these results was co-financed by the Regional Development Fund of the European Community (Brussels, Belgium) in the framework of the Competence Centre Programme of the Enterprise Estonia (Tallinn, Estonia) under project numbers EU22868, EU27789, EU28662, and EU30002 of the Bio-Competence Centre of Healthy Dairy Products (Tervisliku Piima Biotehnoloogiate Arenduskeskus OÜ, Tartu, Estonia), and by Targeted Finance Projects (Tartu, Estonia) 1080045s07 and 1080022s07. The staff from the Estonian Animal Recording Centre (Tartu), the Animal Breeders' Association of Estonia (Keava), and the Institute of Veterinary Medicine and Animal Sciences of the Estonian University of Life Sciences (Tartu) are warmly thanked for their contributions to the collection and laboratory analysis of data for the databases COAGEN and COACAS.

\section{REFERENCES}

Aleandri, R., L. G. Buttazzoni, J. C. Schneider, A. Caroli, and R. Davoli. 1990. The effects of milk protein polymorphisms on milk components and cheese-producing ability. J. Dairy Sci. 73:241255.

Bhandari, V., and H. Singh. 2002. Physical methods. Pages 93-101 in Encyclopedia of Dairy Sciences. Vol. 1. H. Roginski, J. W. Fuquay, and P. F. Fox, ed. Academic Press, San Diego, CA.

Boettcher, P. J., A. Caroli, A. Stella, S. Chessa, E. Budelli, F. Canavesi, S. Ghiroldi, and G. Pagnacco. 2004. Effects of casein haplotypes on milk production traits in Italian Holstein and Brown Swiss cattle. J. Dairy Sci. 87:4311-4317.

Bonfatti, V., G. Di Martino, A. Cecchinato, L. Degano, and P. Carnier. 2010a. Effects of $\beta$ - $\kappa$-casein (CSN2-CSN3) haplotypes and $\beta$-lactoglobulin $(B L G)$ genotypes, and detailed protein composi- tion on coagulation properties of individual milk of Simmental cows. J. Dairy Sci. 93:3809-3817.

Bonfatti, V., G. Di Martino, A. Cecchinato, D. Vicario, and P. Carnier. 2010b. Effects of CSN2-CSN3 haplotypes and BLG genotypes on milk production traits, protein fractions contents and protein composition of individual milk of Simmental cows. J. Dairy Sci. 93:3797-3808

Bovenhuis, H., J. A. M. van Arendonk, and S. Korver. 1992. Associations between milk protein polymorphism and milk production traits. J. Dairy Sci. 75:2549-2559.

Caroli, A. M., S. Chessa, and G. J. Erhardt. 2009. Invited review: Milk protein polymorphisms in cattle: Effect on animal breeding and human nutrition. J. Dairy Sci. 92:5335-5352.

Comin, A., M. Cassandro, S. Chessa, M. Ojala, R. Dal Zotto, M. De Marchi, P. Carnier, L. Gallo, G. Pagnacco, and G. Bittante. 2008. Effects of $\beta$ - and $\kappa$-casein genotypes on milk coagulation, quality, and yield traits in Italian Holstein cows. J. Dairy Sci 91:4022-4027.

Gilmour, A. R., B. J. Gogel, B. R. Cullis, S. J. Welham, and R. Thompson. 2002. ASReml User Guide Release 2.0. VSN International, Hemel Hempstead, UK.

Hallén, E., T. Allmere, J. Näslund, A. Andrén, and A. Lundén. 2007. Effect of genetic polymorphism of milk proteins on rheology of chymosin-induced milk gels. Int. Dairy J. 17:791-799.

Hallén, E., A. Wedholm, A. Andrén, and A. Lundén. 2008. Effect of $\beta$-casein, $\kappa$-casein and $\beta$-lactoglobulin genotypes on concentration of milk protein variants. J. Anim. Breed. Genet. 125:119-129.

Heck, J. M. L., A. Schennink, H. J. F. van Valenberg, H. Bovenhuis, M. H. P. W. Visker, J. A. M. van Arendonk, and A. C. M. van Hooijdonk. 2009. Effects of milk protein variants on the protein composition of bovine milk. J. Dairy Sci. 92:1192-1202.

Ikonen, T., K. Ahlfors, R. Kempe, M. Ojala, and O. Ruottinen. 1999a Genetic parameters for the milk coagulation properties and prevalence of noncoagulating milk in Finnish dairy cows. J. Dairy Sci. 82:205-214.

Ikonen, T., M. Ojala, and O. Ruottinen. 1999b. Associations between milk protein polymorphism and first lactation milk production traits in Finnish Ayrshire cows. J. Dairy Sci. 82:1026-1033.

Ikonen, T., M. Ojala, and E. L. Syvaoja. 1997. Effects of composite casein and $\beta$-lactoglobulin genotypes on renneting properties and composition of bovine milk by assuming an animal model. Agric. Food Sci. Finl. 6:283-294.

ICAR (International Committee for Animal Recording). 2009. International agreement of recording practices. Guidelines approved by the General Assembly held in Niagara Falls, USA, June 18, 2008. Accessed August 4, 2011. http://www.icar.org/Documents/ Rules\%20and\%20regulations/Guidelines/Guidelines_2009.pdf.

Lundén, A., M. Nilsson, and L. Janson. 1997. Marked effect of $\beta$-lactoglobulin polymorphism on the ratio of casein to total protein in milk. J. Dairy Sci. 80:2996-3005.

Macheboeuf, D., J.-B. Coulon, and P. D'Hour. 1993. Effect of breed, protein genetic variants and feeding on cow's milk coagulation properties. J. Dairy Res. 60:43-54.

Mayer, H. K., M. Ortner, E. Tschager, and W. Ginzinger. 1997. Composite milk protein phenotypes in relation to composition and cheesemaking properties of milk. Int. Dairy J. 7:305-310.

McLean, D. M., E. R. B. Graham, R. W. Ponzoni, and H. A. McKenzie. 1984. Effects of milk protein genetic variants on milk yield and composition. J. Dairy Res. 51:531-546.

Ng-Kwai-Hang, K. F., J. F. Hayes, J. E. Moxley, and H. G. Monardes. 1984. Association of genetic variants of casein and milk serum proteins with milk, fat, and protein production by dairy cattle. J. Dairy Sci. 67:835-840.

Ojala, M., T. R. Famula, and J. F. Medrano. 1997. Effects of milk protein genotypes on the variation for milk production traits of Holstein and Jersey cows in California. J. Dairy Sci. 80:1776-1785.

Ojala, M., A.-M. Tyrisevä, and T. Ikonen. 2005. Genetic improvement of milk quality traits for cheese production. Pages 307-311 in Indicators of Milk and Beef Quality. Eur. Assoc. Anim. Prod. Publ. 112. J. F. Hocquette and S. Gigli, ed. Wageningen Academic Publishers, Wageningen, the Netherlands. 
Penasa, M., M. Cassandro, D. Pretto, M. De Marchi, A. Comin, S. Chessa, R. Dal Zotto, and G. Bittante. 2010. Short communication: Influence of composite casein genotypes on additive variation of milk production traits and coagulation properties in HolsteinFriesian cows. J. Dairy Sci. 93:3346-3349.

SAS Institute. 2008. SAS/STAT 9.2 User's Guide. SAS Inst. Inc. Cary, NC.

Vallas, M., H. Bovenhuis, T. Kaart, K. Pärna, H. Kiiman, and E. Pärna. 2010. Genetic parameters for milk coagulation properties in Estonian Holstein cows. J. Dairy Sci. 93:3789-3796.

Velmala, R., E. A. Mäntysaari, and A. Mäki-Tanila. 1993. Molecular genetic polymorphism at the $\kappa$-casein and $\beta$-lactoglobulin loci in Finnish dairy bulls. Agric. Food Sci. Finl. 2:431-435.
Velmala, R., J. Vilkki, K. Elo, and A. Mäki-Tanila. 1995. Casein haplotypes and their association with milk production traits in the Finnish Ayrshire cattle. Anim. Genet. 26:419-425.

Visker, M. H. P. W., B. W. Dibbits, S. M. Kinders, H. J. F. van Valenberg, J. A. M. van Arendonk, and H. Bovenhuis. 2010. Short communication: Association of bovine $\beta$-casein protein variant I with milk production and milk protein composition. Anim. Genet. $42: 212-218$. 